\title{
PERLINDUNGAN HUKUM TERHADAP PEDAGANG PASAR TRADISIONAL KIARACONDONG KOTA BANDUNG ATAS BANGUNAN GEDUNG
}

\author{
Ita Susanti \\ Administrasi Niaga, Politeknik Negeri Bandung \\ Jl. Gegerkalong Hilir Desa Ciwaruga, Kotak Pos 1234, Kabupaten Bandung Barat 40559 \\ E-mail : ita.susanti@polban.ac.id
}

\begin{abstract}
ABSTRAK
Pada kondisi liberalisasi dan globalisasi ekonomi ditandai bermunculan pasar modern seperti supermarket, hypermarket, dan sejenisnya, pasar tradisional tetap memegang peranan penting dalam menggerakkan roda perekonomian di Indonesia bagi masyarakat menengah ke bawah. Untuk menjaga eksistensi pasar tradisional tersebut, pemerintah melakukan penataan terhadap pasar tradisional agar dapat bersaing dengan pasar modern. Berdasarkan UU No. 28 Tahun 2002 tentang Bangunan Gedung, bangunan gedung yang berfungsi sebagai pasar harus memenuhi persyaratan administratif dan persyaratan teknis, terdiri dari persyaratan tata guna lahan dan keandalan bangunan. Namun belum semua pasar memenuhi persyaratan tersebut. Metode yang digunakan dalam penelitian ini adalah yuridis normatif. Penelitian dilakukan dengan tiga tahap. Tahap pertama, studi literatur yaitu menginventarisasi peraturan pasar tradisional dan perlindungan hukum bagi pedagang nya. Tahap kedua penyebaran kuesioner ke pedagang Pasar Tradisional Kiaracondong. Tahap ketiga pembahasan dengan cara membandingkan antara pengaturan hukum secara yuridis normatif tentang perlindungan hukum bagi pedagang pasar tradisional dengan bangunan gedung dan fasilitasnya (das sollen) serta penerapannya dalam kenyataan (das sein). Hasil menunjukkan pedagang pasar yang menempati Pasar Tradisional Kiaracondong terikat sewa menyewa yang menimbulkan hak dan kewajiban. Salah satu kewajiban bagi pedagang tradisional adalah membayar retribusi yang ditetapkan pengelola pasar. Di sisi lain, karakteristik retribusi balas jasa atas pembayaran tersebut dapat diterima oleh pedagang. Bentuk perlindungan hukum bagi pedagang pasar tradisional, PD Pasar Bermartabat Kota Bandung melakukan penataan dan pengelolaan pasar tradisional.
\end{abstract}

Kata kunci: Perlindungan Hukum, Pedagang, Pengelolaan, Pasar Tradisional, Bangunan Gedung

\section{PENDAHULUAN}

Berdasarkan Pasal 33 ayat (4) (UUD 1945) bahwa perekonomian nasional diselenggarakan berdasar atas demokrasi ekonomi dengan prinsip kebersamaan, efisiensi berkeadilan, berkelanjutan, berkawasan lingkungan, kemandirian, serta menjaga keseimbangan, kemajuan dan kesatuan ekonomi nasional. Perwujudan dari kegiatan perekonomian tersebut adalah hadirnya pasar tradisional di tengah masyarakat Indonesia. Menurut sejarah, pasar tradisional sudah ada pada abad ke-5 masehi zaman kerajaan Kutai Kertanegara. Saat itu pasar diawali dengan sistem barter barang kebutuhan sehari-hari dengan para pelaut dari Tiongkok. Pasar juga tidak hanya tempat bertemunya penjual dan pembeli, tetapi sebagai tempat bertemunya masyarakat dan kaum bangsawan. Bahkan pasar dijadikan sebagai bagian strategi politik untuk bertukar informasi penting (Brata et al., 2016).

Perkembangannya pasar tradisional di Indonesia menjadi roda ekonomi kerakyatan. Pasar menjadi tumpuan pedagang kecil dan menengah, juga tumpuan petani, peternak, pengrajin untuk memasarkan produk yang dihasilkannya. Walaupun banyak bermunculan pasar modern dan mall yang menjanjikan kenyamanan dalam berbelanja, jutaan penduduk Indonesia masih mempercayakan pengadaan kebutuhannya pada pasar tradisional (Herman, 2011)

Dari segi tata kelola, menurut Pasal 1 ayat (2) (PERPRES No. 112 Tahun 2007 Tentang Penataan Dan Pembinaan Pasar Tradisional, Pusat Perbelanjaan Dan Toko Modern, 2007), pasar tradisional dapat dikelola oleh pemerintah, swasta, atau Badan Usaha Milik Negara. Setiap pedagang yang berjualan di pasar disediakan tempat usaha berupa toko, kios, los, atau tenda untuk jual beli barang dagangan melalui tawar menawar. Bentuk perikatan antara pengelola dengan pedagang adalah sewa menyewa. Pedagang membayar sejumlah uang tertentu kepada pengelola untuk mendapatkan toko, kios, los, atau diizinkan mendirikan tenda untuk berjualan dengan harga yang telah disepakati.

Sebagai tempat usaha yang dapat menggerakan roda ekonomi masyarakat kelas menengah ke bawah, seharusnya pasar tradisional dikelola dan di fasilitas dengan baik. Selain itu pasar juga merupakan warisan leluhur budaya bangsa Indonesia yang harus dijaga kelestariannya (Pangiuk, 2021). Agar dapat berkompetisi dengan pasar modern, pasar tradisional perlu di tata dan memenuhi standar yang telah ditetapkan sebagai pasar tradisional. Pasar tradisional memiliki umur ekonomis 30 tahun. Bangunan gedung pasar tradisional juga harus 
memenuhi standar keamanan dan keselamatan baik bagi pedagang, pembeli atau pengunjung pasar lainnya (Standar Nasional Indonesia (SNI) 8152:2015 Tentang Pasar Rakyat, 2015). Secara garis besar, agar pembeli mendapat jaminan perlindungan terhadap produk yang diperjualbelikan sesuai dengan ketentuan peraturan perundang-undangan maka setiap pasar tradisional harus menerapkan Standar Nasional Indonesia (SNI) 8152:2015. Selain itu, berdasarkan standar tersebut diatur juga mengenai kondisi fisik bangunan pasar tradisional yang bertujuan untuk melindungi pedagang dan semua pihak yang berkunjung ke pasar tradisional. Bahwa pasar tradisional harus bersih, aman, nyaman dan sehat sehingga dapat bersaing dengan pasar-pasar modern yang perkembangannya sangat pesat.

Salah satu pasar yang berada di Kota Bandung adalah pasar tradisional Kiaracondong, yang dikelola oleh Perusahaan Daerah Pasar Bermartabat Kota Bandung. Berdasarkan SNI 8152:2015 bahwa Pasar Kiaracondong termasuk pada pasar tipe I karena memiliki jumlah pedagang lebih dari 750 pedagang, tepatnya 1059 pedagang. Sementara kapasitas Pasar Kiaracondong hanya untuk 424 pedagang. Artinya kapasitas Pasar Kiaracondong tidak memadai, sehingga pada waktu tertentu seringkali didapatkan kondisi pasar tumpah yang mengakibatkan kemacetan di sepanjang Jl. Ibrahim Adjie. Dari segi bangunan, Pasar Kiaracondong terakhir di renovasi pada tahun 1979, hal ini berarti sudah melebihi umur ekonomis nya. Kondisi ini tentunya akan membahayakan pedagang karena dari segi keamanan dan keselamatan gedung tidak terjamin.

Penelitian sebelumnya mengenai perlindungan hukum yang terkait dengan pasar tradisional sudah pernah dilakukan oleh (Alif Adibatul Lathifah, 2017), dengan hasil perlindungan hukum yang diberikan pemerintah Kota Semarang dalam menjaga eksistensi pasar tradisional adalah dengan melakukan beberapa operasi pengecekan lapangan terkait izin berdagang dengan surat izin yang dikeluarkan oleh pemerintah. Pemerintah akan menindak tegas bagi pedagang yang tidak menaati peraturan dengan sanksi berupa dicabutnya izin berdagang jika ditemukan tidak sesuai nya surat izin dengan kepemilikan toko atau barang yang diperjualbelikan.

Selanjutnya, perlindungan hukum bagi pasar tradisional di era liberalisasi perdagangan dapat dilihat dalam PERPRES No. 112 Tahun 2007 tentang Penataan dan Pembinaan Pasar Tradisional, Pusat Perbelanjaan dan Toko Modern. Akan tetapi melihat perkembangan dan pertumbuhan pasar modern yang kian tak terbendung, maka tidak mustahil keberadaan dan keberlangsungan peran pasar tradisional akan terpinggirkan dan tergusur. Oleh karena itu harus dikendalikan oleh instrumen hukum yang tidak hanya sekadar peraturan (substansi) hukum saja, tetapi juga dibutuhkan komponen lainnya yaitu struktur hukum dan kultur hukum (Dewi, 2018).
Sama halnya dengan penelitian yang telah dilakukan oleh (Wendur, 2020), bahwa jaminan kepastian hukum bagi pelaku usaha/pedagang pasar oleh Pemerintah Daerah Kota Manado sudah cukup baik ditandai dengan adanya PERDA Kota Manado Nomor 1 Tahun 2013 tentang Pengelolaan Perusahaan Daerah Pasar. Pada PERDA tersebut diatur bahwa kegiatan operasional pelaku usaha/pedagang pasar telah menjadi tanggung jawab PD Pasar. Namun dalam PERDA tersebut hak-hak pedagang pasar belum semuanya dapat dilaksanakan oleh PD Pasar.

Berbeda dengan penelitian yang sudah dilakukan sebelumnya, penelitian ini dilakukan untuk mengetahui perlindungan hukum bagi pedagang pasar tradisional dari sisi kelayakan bangunan gedung dan fasilitasnya (UU No.28 Tahun 2002 Tentang Bangunan Gedung, 2002). Pasar Tradisional Kiaracondong sendiri terakhir direnovasi pada tahun 1979, sehingga pasar ini terlihat sangat kumuh dan sudah tidak dapat menampung kapasitas jumlah pedagang lagi. Sementara dari sisi pengelolaan, Pasar Kiaracondong ini dikelola oleh Pemerintah Daerah Kota Bandung dan seluruh pedagang yang berjualan di sana dikenakan retribusi daerah atas penggunaan fasilitas pasar. Apabila kita memperhatikan karakteristik retribusi, setiap pembayaran retribusi ada kontra prestasi secara langsung dan retribusi dikenakan pada setiap orang/badan yang menggunakan fasilitas negara (Maulida, 2019). Sementara para pedagang di Pasar Tradisional Kiaracondong tidak mendapatkan kontra prestasi tersebut karena kondisi pasar sudah tidak layak dan dapat membahayakan pedagang dari segi keamanan dan keselamatan.

\section{RUANG LINGKUP}

Kondisi pasar tradisional yang bersih, nyaman dan sehat merupakan salah satu daya tarik pembeli untuk berbelanja. Selain produk yang dijual tidak bertentangan dengan peraturan perundang-undangan, kondisi bangunan gedung juga menjadi dasar pertimbangan pembeli untuk berbelanja di suatu pasar tradisional. Bangunan pasar yang sudah tua, mulai terjadi kerusakan dimana-mana selain dapat membahayakan pedagang pasar juga dapat membahayakan pengunjung yang datang ke pasar tersebut. Di sisi lain, pedagang pasar juga harus pungutan atau retribusi sejumlah uang tertentu agar dapat berjualan di pasar tersebut. Sehingga wajar apabila pedagang menuntut fasilitas yang seharusnya ada pada sebuah pasar.

Perlindungan hukum terhadap pedagang pasar tradisional sangat diperlukan mengingat kondisi saat ini metode berdagang mulai merambah pada dunia maya yaitu dengan hadirnya e-commerce yaitu sistem berbelanja secara online yang menjanjikan kemudahan bagi pembeli dengan jangkauan yang luas serta mampu melayani berbagai kebutuhan pembeli. Selain pasar modern yang menjadi pesaing utama dari pasar tradisional, dengan kemajuan informasi dan teknologi kini telah hadir juga e-commerce yang keduanya 
menjanjikan kenyamanan dan kemudahan dalam berbelanja.

Hasil penelitian akan sangat membantu dalam edukasi para pedagang Pasar Tradisional Kiaracondong berkaitan dengan perlindungan hukum atas bangunan tempat berjualan termasuk fasilitas yang hendaknya diterima pedagang karena adanya perikatan antara pengelola pasar dan pedagang baik berupa sewa menyewa ataupun jual beli. Hasil penelitian berupa pemahaman dari pedagang Pasar Tradisional Kiaracondong diharapkan dapat membantu untuk menata pasar tradisional agar mampu bersaing dengan pasar modern ditengah-tengah pengaruh globalisasi dan liberalisasi ekonomi.

\section{BAHAN DAN METODE}

Penelitian ini merupakan penelitian yuridis normatif, yaitu suatu prosedur penelitian ilmiah untuk menemukan kebenaran berdasarkan logika keilmuan hukum dari sisi normatif nya. Dalam kajian ini, hukum dilihat sebagai sebuah sistem tersendiri yang terpisah dengan berbagai sistem lain yang ada di dalam masyarakat sehingga memberi batas antara sistem hukum dengan sistem lainnya (Ibrahin, 2007). Penelitian yang dilakukan bermaksud menganalisa secara yuridis perlindungan terhadap pedagang pasar tradisional dari aspek bangunan gedung serta fasilitas yang seharusnya terdapat dalam bangunan pasar.

Penelitian dilakukan dalam tiga tahap. Tahap pertama, studi literatur sebagai studi pendahuluan, yaitu menginventarisasi peraturan perundang-undangan terkait dengan pengaturan pasar tradisional dan perlindungan hukum bagi pedagang nya. Tahap kedua penyebaran kuesioner ke pedagang Pasar Tradisional Kiaracondong. Langkah berikutnya adalah wawancara dengan pengelola pasar. Tahap ketiga berupa pembahasan analisis dengan cara membandingkan antara pengaturan hukum secara yuridis normatif tentang perlindungan hukum bagi pedagang pasar tradisional berkaitan dengan bangunan gedung dan fasilitasnya (das sollen) serta penerapannya dalam kenyataan (das sein).

Pengumpulan data tentang pemahaman pedagang tradisional berkaitan dengan perlindungan hukum dari aspek bangunan gedung dilakukan dengan penyebaran kuesioner. Sebagai respondennya adalah pedagang Pasar Tradisional Kiaracondong Kota Bandung. Kuesioner terdiri dari 22 pertanyaan campuran, 20 pertanyaan merupakan pertanyaan tertutup dengan 5 opsi jawaban yang telah disediakan yaitu, sangat tidak setuju, tidak setuju, netral, setuju, dan sangat setuju. Kemudian 2 pertanyaan merupakan pertanyaan yang sifatnya terbuka, artinya responden diminta untuk menjawab pertanyaan dengan jawaban seluas-luasnya berdasarkan pemahaman dan pengetahuannya. Kuesioner yang diberikan dijadikan sebagai panduan untuk menarik kesimpulan dari setiap pertanyaan terkait pengetahuan responden mengenai perlindungan hukum pedagang tradisional dari aspek bangunan gedung. Pemberian skor pada setiap jawaban kuesioner untuk menyimpulkan tingkat pemahaman berdasarkan kriteria dapat dilihat pada tabel 1 .

Tabel 1.Kriteria Tingkat Pemahaman Terhadap Perlindungan Hukum Pedagang

\begin{tabular}{|c|c|}
\hline Skor & Ukuran Penilaian \\
\hline 1 & Sangat Tidak Setuju \\
\hline 2 & Tidak Setuju \\
\hline 3 & Netral \\
\hline 4 & Setuju \\
\hline 5 & Sangat Setuju \\
\hline
\end{tabular}

\section{PEMBAHASAN}

Sesuai dengan misi nawacita, pasar merupakan cerminan dari ekonomi kerakyatan. Agar pasar tradisional dan pasar modern dapat bersaing secara fair dan tidak bertentangan dengan peraturan perundangundangan sehingga dapat bersaing dengan sehat, maka pasar tradisional perlu dikelola dan ditata dengan baik. Seperti yang diatur dalam (UU No.5 Tahun 1999 Tentang Larangan Praktik Monopoli Dan Persaingan Usaha Tidak Sehat, 1999), bahwa persaingan usaha yang sehat adalah persaingan usaha yang dilakukan dengan cara-cara yang jujur, tidak bertentangan dengan peraturan perundang-undangan dan tidak menghambat pesaing lain masuk pada pasar yang sama. Dengan demikian secara persaingan antara pasar tradisional dengan pasar modern diupayakan mempunyai daya tawar (bargaining position) yang sama.

\subsection{Pengaturan Mengenai Pasar Tradisional}

Pengaruh globalisasi dan liberalisasi perdagangan telah membuka peluang investasi dalam bidang pembangunan ekonomi. Tentunya investasi ekonomi menjadi aspek penting dalam perekonomian suatu negara karena dapat menggerakan proses penguatan perekonomian. Namun apabila investasi tidak dikelola dan ditata dengan baik akan menimbulkan dampak negatif bagi sektor usaha lainnya, antara lain masuknya investasi di sektor industri ritel modern yang tidak terbendung. Di satu sisi pertumbuhan industri ritel modern dapat meningkatkan pertumbuhan ekonomi bagi masyarakat, namun pada sisi lain dapat mematikan industri rumah tangga, seperti pedagang kecil, usaha mikro, kecil dan menengah yang berusaha di pasar tradisional.

Dengan demikian eksistensi pasar tradisional terancam dengan kehadiran pasar modern yang pertumbuhannya semakin meningkat. Hal ini karena dalam pasar modern memiliki beberapa kelebihan jika dibandingkan dengan pasar tradisional, antara lain; barang yang dijual memiliki kualitas yang terjamin, tempat yang luas, nyaman dan bersih, pembeli bebas melihat dan memilih barang sendiri, terdapat diskon atau promo yang menarik terhadap suatu produk tertentu. Namun tidak menutup kemungkinan juga terdapat kekurangan dari pasar modern antara lain; menarik 
pembeli dari pasar tradisional, tidak terjadi tawar menawar, terjadi eksploitasi terhadap pemasok, adanya kesenjangan ekonomi antara pasar modern dan pasar tradisional.

Agar dapat mengetahui lebih jauh lagi mengenai fenomena antara pengaturan hukum tentang pasar tradisional (das sollen) serta penerapannya dalam kenyataan (das sein) maka peneliti menyebarkan kuesioner di pasar tradisional Kiaracondong dengan responden adalah para pedagang di pasar tersebut. Berdasarkan data responden yang masuk terdapat 100 orang yang mengisi kuesioner dan memberikan tanggapan mengenai gambaran umum kondisi pasar yang dapat dilihat pada gambar 1 berikut ini:

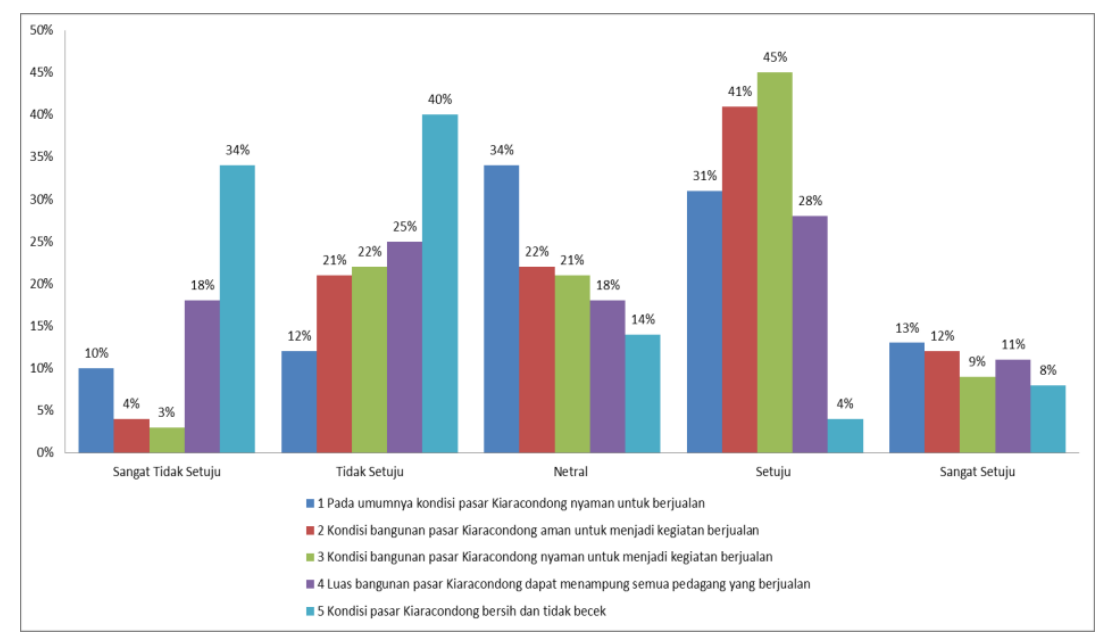

Gambar 1. Kondisi Bangunan Pasar Kiaracondong

Pada gambar 1, umumnya pedagang merasa nyaman dengan kondisi Pasar Tradisional Kiaracondong pada saat ini, 31\% responden menjawab setuju dengan kondisi tersebut. Selanjutnya pedagang masih merasa aman dengan kondisi bangunan pasar saat ini, $41 \%$ responden menjawab setuju. Kemudian berkaitan dengan kenyamanan bangunan gedung $45 \%$ responden menjawab setuju bahwa bangunan gedung Pasar Kiaracondong masih nyaman untuk berjualan. Pada kondisi luas bangunan pasar, pedagang masih menganggap setuju, 28\% responden menjawab bahwa Pasar Kiaracondong masih dapat menampung jumlah pedagang yang ada pada saat ini. Berikutnya berkaitan dengan kondisi pasar, responden menjawab $40 \%$ tidak setuju bahwa Pasar Kiaracondong bersih dan tidak becek. Artinya kondisi pasar kotor dan becek, terutama jika setelah hujan.

Dalam rangka meningkatkan daya saing pasar tradisional terhadap pasar modern, maka pemerintah melakukan penataan terhadap pasar tradisional. Salah satunya adalah seperti yang diatur dalam PERPRES No. 112 Tahun 2007 tentang Penataan dan Pembinaan Pasar Tradisional, Pusat Perbelanjaan dan Toko Modern. Pada Pasal 2 ayat (2) PERPRES tersebut diatur bahwa pendirian pasar tradisional harus memenuhi beberapa ketentuan antara lain:

1. Memperhitungkan kondisi sosial ekonomi masyarakat dan keberadaan pasar tradisional, pusat perbelanjaan dan toko modern serta usaha kecil, termasuk koperasi;
2. Menyediakan areal parkir;

3. Menyediakan fasilitas yang menjamin Pasar Tradisional yang bersih, sehat (hygienist), aman, tertib dan memiliki ruang publik yang nyaman.

Berdasarkan pasal tersebut dihubungkan dengan jawaban responden maka Pasar Tradisional Kiaracondong belum memenuhi unsur kebersihan dan kesehatan. Responden setuju bahwa kondisi Pasar Kiaracondong masih kotor dan becek. Hal ini tentunya belum memenuhi sebagai prasyarat pasar tradisional yang sesuai peraturan.

Menjaga kebersihan dan kesehatan kondisi pasar tidak terlepas dari peran serta dan tanggung jawab dari pihak pengelola pasar dan pedagang pasar itu sendiri. Perusahaan Daerah (PD) Pasar Bermartabat menurut (PERDA Kota Bandung No. 15 Tahun 2007 Tentang Perusahaan Daerah Pasar Bermartabat Kota Bandung, 2017) adalah perusahaan daerah yang mengelola pasar tradisional di Kota Bandung. Sesuai dengan kegiatan usahanya PD Pasar Bermartabat dapat mendirikan, membangun dan/atau mengelola fasilitas pasar.

Pertanyaan selanjutnya yang diajukan kepada responden adalah berkaitan dengan pemeliharaan pasar oleh pihak pengelola. Jawaban responden dapat dilihat pada gambar 2 . 


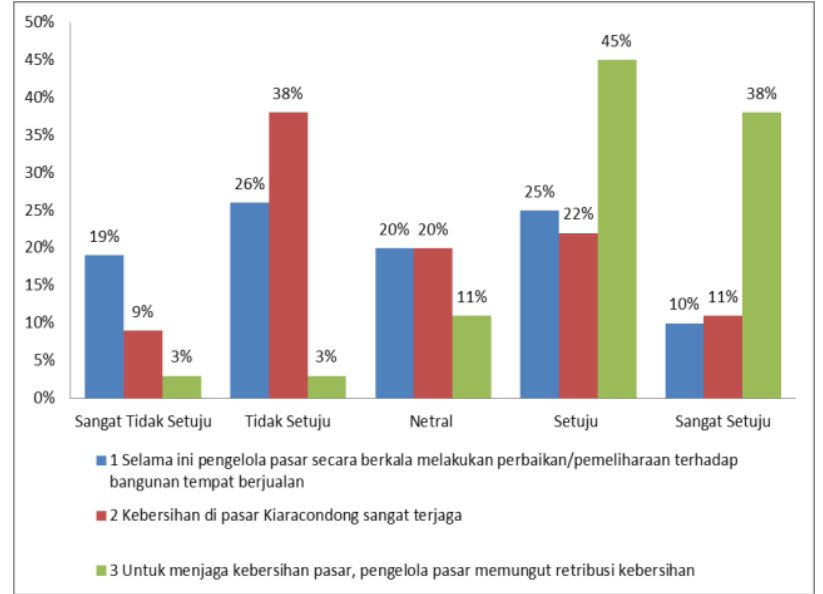

Gambar 2. Pemeliharaan oleh Pengelola

Berdasarkan jawaban responden, pedagang pasar $26 \%$ menjawab tidak setuju bahwa pengelola pasar secara rutin melakukan perbaikan atau pemeliharaan terhadap bangunan gedung. Artinya memang pengelola pasar tidak melakukan perbaikan atau pemeliharaan secara rutin terhadap bangunan pasar. Termasuk juga jawaban responden yang berkaitan dengan kebersihan pasar, responden 38\% menjawab tidak setuju jika Pasar Kiaracondong sudah dalam kondisi bersih. Sementara responden atau pedagang secara rutin ditarik retribusi untuk kebersihan pasar, dapat dilihat pada jawaban responden $45 \%$ yang menjawab setuju bahwa pengelola pasar memungut retribusi untuk kebersihan.

Sesuai dengan (Standar Nasional Indonesia (SNI) 8152:2015 Tentang Pasar Rakyat, 2015) bahwa prasyarat umum pasar harus memenuhi aspek Keselamatan dan Kesehatan Kerja (K3) juga aspek kenyamanan dan kemudahan. Hal tersebut juga menjadi pertanyaan yang diajukan terhadap responden dengan jawaban seperti pada gambar 3 .

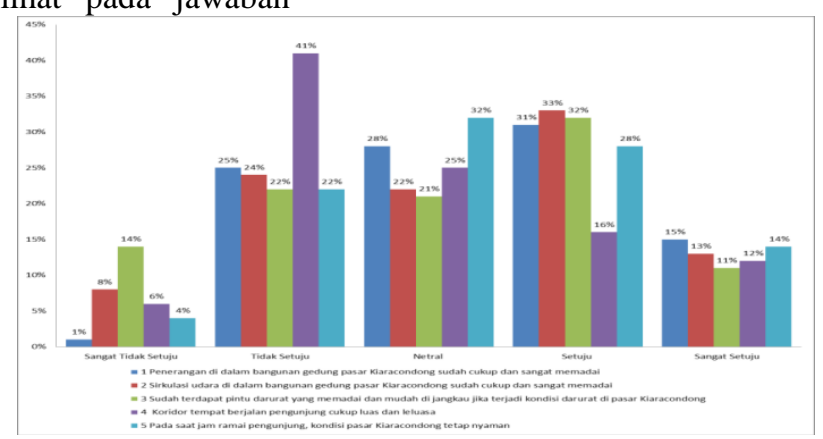

Gambar 3. Aspek K3

Berdasarkan jawaban responden pada gambar 3, penerangan di Pasar Kiaracondong sudah cukup dan memadai untuk melakukan aktivitas di dalam gedung pasar tersebut dengan menjawab $31 \%$ setuju dengan kondisi tersebut. Selanjutnya sirkulasi udara di dalam bangunan gedung pasar sudah cukup memadai dengan jawaban 33\% responden setuju. Kemudian di Pasar Kiaracondong juga sudah terdapat pintu "Exit" untuk kondisi keadaan darurat, jawaban responden 32\% setuju. Sedangkan untuk kondisi koridor tempat berjalan yang luas dan leluasa $41 \%$ responden menjawab tidak setuju. Kemudian pada pertanyaan kondisi yang tetap nyaman pada saat pasar sedang ramai, responden paling banyak menjawab netral 32\% jawaban.

Dari aspek K3 dan kenyamanan, Pasar Kiaracondong belum memenuhi aspek kenyamanan bangunan gedung terutama pada saat kondisi jam pasar sedang sibuk. Ketidaknyamanan tersebut karena koridor atau ruang antara pedagang yang satu dengan yang lain untuk tempat berjalan pengunjung sempit sehingga membuat tidak nyaman.

Aspek yang terpenting lainnya dari aktivitas di pasar tradisional yaitu yang berkaitan dengan aspek legalitas, pada gambar 4 berikut ini jawaban responden berkaitan dengan hal tersebut. 


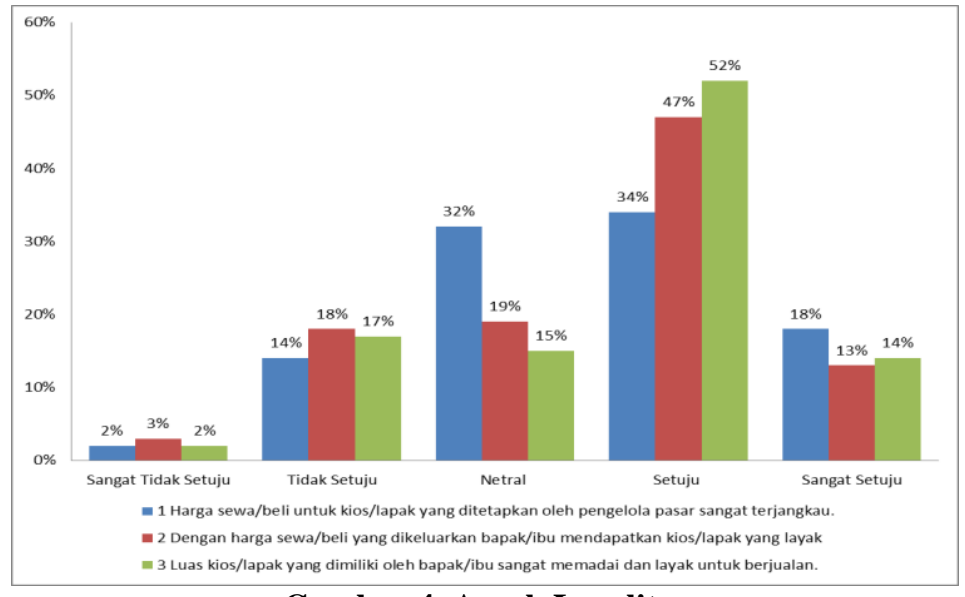

Gambar 4. Aspek Legalitas

Mengenai aspek legalitas, pedagang Pasar Kiaracondong ada yang mendapatkan tempat berjualan dengan cara menyewa atau membeli. Luas bangunan pasar Kiaracondong adalah $5000 \mathrm{~m} 2$ para pedagang berjumlah 1057 ruang dagang (Sabhira \& Susanti, 2021). Berdasarkan jawaban responden, dari harga sewa atau beli yang dikeluarkan oleh pedagang, 34\% menjawab harga tersebut terjangkau dan sepadan dengan kios, toko, atau los yang didapatkan layak untuk tempat berdagang
$47 \%$ responden menjawab setuju, dan $52 \%$ responden menjawab setuju bahwa tempat berdagang yang didapat dengan harga sewa atau harga beli yang didapatkan memadai dan layak untuk berdagang.

Aspek lainnya yang mendukung pada kegiatan di pasar tradisional adalah adanya fasilitas pendukung yang memadai sesuai dengan peraturan perundang-undangan. Pada gambar 5 berikut ini adalah jawaban dari responden berkaitan dengan fasilitas pendukung.

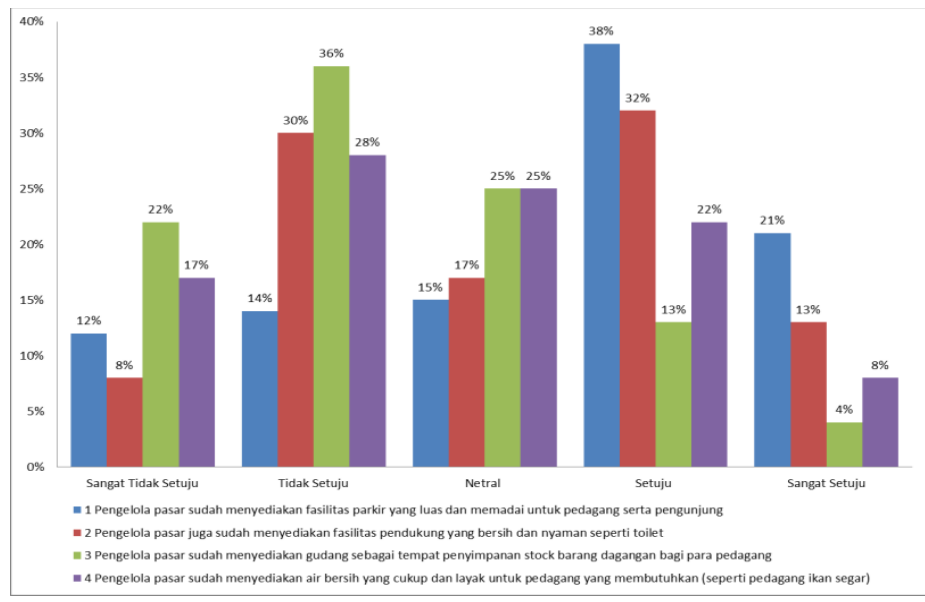

Gambar 5. Fasilitas Pendukung Pasar

Pasar tradisional yang sesuai dengan peraturan harus memiliki fasilitas pendukung terutama dengan fasilitas tempat parkir yang luas untuk pedagang dan pengunjung pasar. Hal ini diperlukan apabila pasar tradisional tidak menyediakan tempat parkir yang luas maka pengunjung pasar pada kondisi pasar pada jam ramai akan menggunakan bahu jalan untuk parkir sehingga akan mengakibatkan kemacetan di sekitar jalan pasar tersebut. Kondisi ini hampir sama dengan yang terjadi pada Pasar Tradisional Kiaracondong, pada jam sibuk terjadi kemacetan di sepanjang sekitar pasar.

Selain fasilitas pendukung tempat areal parkir, fasilitas yang berhubungan dengan kebersihan, kesehatan dan higienis kondisi pasar juga menjadi hal yang utama dalam keberadaan pasar tradisional yang sesuai dengan peraturan, seperti jawaban responden 32\% menjawab setuju bahwa sudah terdapat toilet yang cukup memadai. Akan tetapi fasilitas gudang $36 \%$ responden menjawab tidak setuju karena pengelola tidak menyediakan gudang untuk penyimpanan stock barang yang dimiliki oleh pedagang. Hal yang serupa juga terjadi pada penyediaan air bersih yang cukup dan layak untuk pedagang yang membutuhkan air bersih seperti misalnya pedagang ikan. Responden menjawab 28\% tidak setuju bahwa Pasar Kiaracondong telah menyediakan fasilitas air bersih.

Dari beberapa pertanyaan yang diajukan dan jawaban responden pada umumnya Pasar Tradisional 
Kiaracondong masih cukup layak untuk beroperasi hanya saja untuk

beberapa fasilitas sudah tidak memenuhi persyaratan peraturan mengingat kondisi pasar yang sudah cukup lama sudah tidak direnovasi. Sehingga apabila tujuan penataan pasar tradisional adalah agar pasar dapat bersaing dengan pasar modern, maka Pasar Tradisional Kiaracondong ini perlu dilakukan penataan kembali agar memiliki daya saing dengan pasar modern.

\subsection{Perlindungan Hukum Terhadap Pedagang Pasar Tradisional Dari Aspek Bangunan Gedung \\ Sesuai dengan (UU No.28 Tahun 2002 Tentang} Bangunan Gedung, 2002), sebuah gedung harus memenuhi persyaratan administratif dan persyaratan teknis sesuai dengan fungsi bangunan gedung. Persyaratan administrasi meliputi persyaratan status hak atas tanah, status kepemilikan bangunan gedung, dan izin mendirikan bangunan. Berdasarkan hasil observasi di lapangan, Pasar Tradisional Kiaracondong sudah memenuhi persyaratan administrasi secara umum. Antara pengelola pasar, PD Pasar Bermartabat dengan pedagang pasar sudah ada alas hak yang sah, baik itu sewa menyewa ataupun jual beli, dengan harga yang telah disepakati dan disetujui oleh kedua belah pihak.

Persyaratan teknis meliputi persyaratan tata bangunan dan persyaratan keandalan bangunan. Berkaitan persyaratan tata bangunan, berdasarkan hasil wawancara dengan pihak pengelola pasar diketahui data seperti yang tercantum dalam tabel 2 .

Tabel 2. Tata Guna Lahan Pasar Kiaracondong

\begin{tabular}{|c|c|c|}
\hline No & Tata Guna Lahan & Keterangan \\
\hline 1. & TUPOKSI Lahan & Perdagangan \\
\hline 2. & Koefisiensi Dasar Bangunan (KDB) & $70 \%$ \\
\hline 3. & Koefisiensi Dasar Hijau (KDH) & $20 \%$ \\
\hline 4. & Koefisiensi Lantai Bangunan (KLB) & 2,1 \\
\hline 5. & Garis Sempadan Bangunan & $1 / 2$ x Lebar Rumija \\
\hline
\end{tabular}

Perhitungan tersebut merupakan perhitungan berdasarkan peraturan, seharusnya kondisi pasar memiliki luas dan tata guna lahan sesuai dengan perhitungan di atas. Berdasarkan hasil wawancara pengaturan berdasarkan tata guna lahan tersebut tidak didapatkan secara jelas dan rinci. Mengingat kondisi pasar juga yang sudah lama tidak direnovasi sementara saat ini pasar menampung banyak pedagang yang tidak sesuai dengan kapasitas pasar.

Selanjutnya persyaratan bangunan berikutnya adalah persyaratan keandalan bangunan, yang meliputi keselamatan, kesehatan, kenyamanan dan kemudahan. Pada bangunan Pasar Kiaracondong, kondisi pasar sudah melebihi kapasitas bangunan gedung. Jumlah pedagang pasar memiliki jumlah yang melebihi kapasitas pasar yang seharusnya. Berdasarkan hasil observasi terdapat sejumlah 1059 pedagang, sementara kapasitas pasar hanya untuk 424 pedagang. Dalam hal ini Pasar Kiaracondong belum memenuhi syarat keandalan bangunan dari aspek keselamatan, ditambah lagi kondisi bangunan gedung sudah lama tidak direnovasi. Hal ini tentunya tidak dapat menjamin keselamatan pedagang pasar yang jumlahnya lebih dari seribu pedagang. Sementara pedagang tentunya sudah mengeluarkan biaya untuk sewa atau jual beli los, kios, atau toko yang sudah didapatkan untuk berdagang ditambah lagi pedagang secara rutin ditarik retribusi oleh pengelola pasar.

Berikutnya persyaratan keandalan bangunan gedung dari aspek kesehatan yang meliputi sistem penghawaan, pencahayaan, sanitasi, dan penggunaan bahan bangunan gedung. Dari sisi penghawaan dan pencahayaan pasar Tradisional Kiaracondong sudah memenuhi aspek tersebut hanya bagian sanitasi yang belum terpenuhi karena fasilitas yang berkaitan dengan hal tersebut masih minim. Kemudian dari aspek penggunaan bahan bangunan, karena kondisi pasar terakhir di renovasi tahun 1979 maka penggunaan bahan belum menggunakan konsep yang ramah lingkungan.

Pada persyaratan keandalan bangunan berikutnya adalah aspek kenyamanan dan kemudahan. Dari aspek kenyamanan, Pasar Kiaracondong belum memenuhi aspek kenyamanan ruang gerak dan hubungan antar ruang yang ideal. Koridor yang tersedia tidak memenuhi standar yang diatur dalam SNI 8152:2015, koridor terasa sempit apalagi ketika kondisi pasar sedang ramai pengunjung. Sementara apabila dilihat dari aspek kemudahan hubungan di dalam bangunan gedung sudah terpenuhi.

\subsection{Upaya Pemerintah Daerah Kota Bandung Dalam Menata Pasar Tradisional}

Seperti yang telah dikemukakan sebelumnya bahwa Pasar Tradisional Kiaracondong di kelola oleh Perusahaan Daerah (PD) Pasar Bermartabat Kota Bandung. Berdasarkan PERDA Kota Bandung No. 15 Tahun 2007 tentang Perusahaan Daerah Pasar Bermartabat Kota Bandung, tugas pokok PD Pasar Bermartabat adalah menyelenggarakan pengelolaan pasar dalam rangka menunjang perekonomian dan pendapatan asli daerah. Untuk melaksanakan tugasnya tersebut, PD Pasar Bermartabat dapat melaksanakan fungsi perumusan kebijakan pengelolaan aset pasar beserta fasilitasnya, perencanaan pengelolaan aset pasar dan fasilitasnya, pembangunan dan menyelenggarakan pengelolaan aset pasar serta melakukan evaluasi terhadap aset pasar beserta fasilitasnya. 
Hal tersebut tentunya sejalan dengan yang dilakukan oleh Pemerintah Kota Bandung dalam menata pasar tradisional, seperti yang diatur dalam (PERDA No. 2 Tahun 2009 Tentang Penataan Pasar Tradisional, Pusat Perbelanjaan Dan Toko Modern, 2009). Dalam PERDA tersebut, pemerintah daerah menjamin iklim perdagangan yang sehat dan memberikan kesempatan yang sama dan dukungan berusaha yang seluas-luasnya bagi setiap pelaku usaha. Berdasarkan PERDA tersebut, maka pelaku usaha harus mematuhi persaingan usaha yang sehat seperti yang diatur dalam UU No. 5 Tahun 1999 tentang Larangan Praktik Monopoli dan Persaingan Usaha Tidak Sehat. Bahwa persaingan usaha yang sehat adalah persaingan yang dilakukan oleh pelaku usaha dengan cara-cara yang jujur, tidak melawan hukum, dan tidak menghambat pelaku usaha lain untuk masuk pada pasar yang sama.

Sehingga untuk menciptakan iklim perdagangan yang kondusif tersebut maka pemerintah daerah melakukan penataan terhadap pasar tradisional, pusat perbelanjaan dan toko modern. Tujuannya agar pasar tradisional dapat bersaing dengan pasar modern. Dalam hal ini pemerintah daerah mengatur lokasi dan jarak tempat usaha perdagangan antara pasar tradisional dengan pusat perbelanjaan, dan pasar tradisional dengan toko modern. Lokasi pendirian pasar tradisional, pusat perbelanjaan dan toko modern tersebut tentunya harus mengacu kepada Rencana Tata Ruang Wilayah dan Rencana Tata Ruang Kota serta aturan zonasi nya. Serta kemungkinan dibentuknya kemitraan antara pedagang pasar tradisional dengan toko modern.

Sebagai pengelola pasar tradisonal di Kota Bandung, PD Pasar Bermartabat memungut biaya pemeliharaan pasar berdasarkan (PERWAL No. 166 Tahun 2017 Tentang Tarif Jasa PD Pasar Bermartabat, 2017.). Biaya yang dipungut tersebut adalah untuk pelayanan atas jasa pelayanan fasilitas pasar, fasilitas ketertiban, dan fasilitas kebersihan. Besarnya pungutan tergantung dari kelas pasar, letak tempat usaha, jenis tempat usaha dan luas tempat usaha. Pemungutan sejumlah uang yang ditarik dari subjek hukum atas fasilitas yang diterima dari pemerintah daerah di sebut dengan retribusi.

Perbedaan antara objek retribusi daerah dengan pajak daerah adalah pada retribusi daerah orang yang menggunakan jasa pemerintahan dan pelayanan umum seperti kesehatan, terminal, pasar (Sandi, 2019). Sementara objek pajak daerah adalah penghasilan, barang mewah, kendaraan, laba perusahaan dan lainnya. Kemudian balas jasa untuk retribusi daerah dapat dirasakan langsung sedangkan pajak daerah balas jasanya tidak dapat dirasakan langsung. Adapun lembaga pemungutannya adalah untuk retribusi daerah pemerintah daerah dalam hal ini dinas pendapatan daerah, sementara pajak daerah dipungut oleh pemerintah daerah maupun pemerintah pusat.

Seperti yang telah dilakukan oleh PD Pasar Bermartabat Kota Bandung, yaitu memungut biaya atas penggunaan fasilitas pasar yang sudah digunakan oleh pedagang pasar, termasuk juga pada pedagang di Pasar Kiaracondong. Tujuannya adalah sebagai kontra prestasi atas pelayanan jasa yang didapatkan pedagang pasar karena sudah menggunakan fasilitas yang disediakan PD Pasar Bermartabat Kota Bandung. Sesuai dengan karakteristik retribusi bahwa balas jasa akan diterima secara langsung, maka pada pemungutan biaya atas fasilitas pasar dapat dirasakan secara langsung oleh para pedagang. Pengelola pasar melakukan pemeliharaan terhadap kebersihan, ketertiban dan kesehatan pasar.

Fasilitas utama dari pasar yaitu bangunan gedung, berdasarkan hasil wawancara dengan pengelola, Pasar Kiaracondong terakhir di renovasi tahun 1979. Dalam waktu dekat belum ada rencana untuk di renovasi mengingat juga kondisi saat ini seluruh dunia sedang mengalami pandemi termasuk di Indonesia, sehingga dari pihak pengelola berdasarkan tuntutan kondisi lebih mengutamakan penerapan protokol kesehatan di pasar tradisional. Sejak awal pemerintah mengumumkan kondisi pandemi covid-19, PD Pasar Bermartabat juga telah bersinergi dan mengantisipasi dengan upaya-upaya pencegahan virus covid-19 salah satunya adalah dengan cara pembuatan bilik sterilisasi di pasar-pasar tradisional (Yudatama, 2020).

Berdasarkan hal tersebut, walaupun kondisi bangunan Pasar Tradisional Kiaracondong sudah tua dan butuh untuk segera di renovasi, namun karena kondisi kenyataan tidak memungkinkan, maka belum ada perencanaan dan tindakan dari PD Pasar Bermartabat Kota Bandung melakukan pemeliharaan fasilitas gedung.

\section{KESIMPULAN}

Pengaruh liberalisasi dan globalisasi ekonomi membuat pemerintah mengundangkan peraturan yang menata pasar tradisional dan pasar modern. Hal ini agar pasar tradisional dapat bersaing dengan pasar modern, mengingat kecenderungan pembeli untuk berbelanja di tempat yang bersih, aman, dan nyaman.

Secara garis besar kondisi bangunan Pasar Tradisional Kiaracondong masih dapat digunakan untuk menampung pedagang berjualan. Walaupun kondisinya melebihi kapasitas pasar seharusnya. Terdapat beberapa fasilitas yang tidak didapat pedagang sebagai bentuk perlindungan hukum pedagang pasar tradisional.

Pemerintah Daerah Kota Bandung melalui PD Pasar Bermartabat melalukan penataan dan pengelolaan terhadap pasar-pasar tradisional. Sebagai kontra prestasinya PD Pasar Bermartabat memungut retribusi atas penggunaan fasilitas yang telah diterima oleh pedagang pasar tradisonal.

\section{SARAN}

Perlu dibangun kesadaran hukum pedagang tradisional untuk mendapatkan perlindungan hukum yang setimpal atas perbuatan hukum yang telah dilakukan. Bagi pedagang tradisional yang telah terikat pada perjanjian sewa menyewa maka akan muncul hak 
dan kewajiban yang harus dipenuhi oleh kedua belah pihak.

Perlu dilakukan tindakan yang serius dari pemerintah daerah dalam menata pasar tradisional, sehingga pasar tradisional yang merupakan warisan budaya Bangsa Indonesia tidak hilang.

\section{DAFTAR PUSTAKA}

Alif Adibatul Lathifah, W. (2017). Peran Pemerintah Daerah Dalam Memberikan Perlindungan Hukum Terhadap Keberadaan Pasar Tradisional Di Kota Semarang. Jurmal Hukum Khaira Ummah, 12(3).

Brata, I. (2016). Pasar Tradisional Di Tengah Arus Budaya Global. Jurnal Ilmu Manajemen Mahasaraswati, 6(1), 102449.

Dewi, N. K. D. (2018). Perlindungan Hukum Terhadap Pasar Tradisional Di Era Liberalisasi Perdagangan. Law Reform, 14(1). https://doi.org/10.14710/lr.v14i1.20232

Herman, M. (2011). Selamatkan Pasar Tradisional: Potret Ekonomi Rakyat Kecil. Gramedia.

Ibrahin, J. (2007). Teori dan Metodelogi Penelitian Hukum Normatif. Banyumedia.

Maulida, R. (2019). Perbedaan Pajak, Retrubusi, dan Sumbangan. https://www.onlinepajak.com/seputar-pajak-pribadi/perbedaanpajak-retribusi-dan-sumbangan.

Pangiuk, A. (2021). Strategi Daya Saing Pasar Tradisional di Indonesia. Forum Pemuda Aswaja.

Sandi, F. B. (2019). Retribusi Daerah: Pengertian, Jenis, Tarif, dan Perbedaannya dari Pajak Daerah. https://www.online-pajak.com/tentang-pajakpribadi/retribusi-daerah

Sabhira, P. R., \& Susanti, I. (2021). Evaluasi Kinerja Aset Pasar Tradisional Kiaracondong Kota Bandung. IRWNS, 12, 4-5.

Wendur, R. S. (2020). Perlindungan Hukum Terhadap Pelaku Usaha Mikro, Kecil dan Menengah di Bidang Ritel di Kota Manado. Lex administratum, $8(2)$.

Yudatama, S. (2020). Cegah Covid-19 Bilik Strerilisasi akan Hadir di Pasar Tradisional. https://www.pikiran-rakyat.com/bandung-raya/pr01355361/cegah-covid-19-bilik-sterilisasi-akanhadir-di-pasar-pasar-tradisional-kota-bandung.

UU No.5 Tahun 1999 Tentang Larangan Praktek Monopoli dan Persaingan Usaha Tidak Sehat, (1999).

UU No.28 Tahun 2002 Tentang Bangunan Gedung, (2002)

Perpres No. 112 Tahun 2007 Tentang Penataan dan Pembinaan Pasar Tradisional, Pusat Perbelanjaan dan Toko Modern, (2007).

Perda Kota Bandung No. 15 Tahun 2007 tentang Perusahaan Daerah Pasar Bermartabat Kota Bandung, (2017).
Perda No. 2 Tahun 2009 tentang Penataan Pasar Tradisional, Pusat Perbelanjaan dan Toko Modern, (2009).

Perwal No. 166 tahun 2017 tentang Tarif Jasa PD Pasar Bermartabat.

\section{UCAPAN TERIMAKASIH}

Ucapan terima kasih Peneliti sampaikan kepada Politeknik Negeri Bandung melalui P3M yang telah membiayai penelitian ini yang bersumber dari DIPA

Politeknik Negeri Bandung sesuai dengan Surat Perjanjian Pelaksanaan Kegiatan Penelitian Mandiri No. 105.100/PL1.R7/PG.00.03/2021. 